\title{
Stephen Erwin Moorbath (Magdeburg, 9 May 1929 - Oxford, 16 October 2016)
}

One of the greatest British and world's geochronologists passed away on October 16, 2016. He was the founder (in 1956-1958) and leader for long years of the Geological Age and Isotope Research Group at the University of Oxford, and Professor Emeritus (after retirement) at Linacre College. His scientific life was dedicated to the research on the oldest rocks on Earth, and of their reworking during later geological processes. The fieldwork he performed covered highgrade metamorphic terranes in Greenland, Scotland, India, Zimbabwe, and metamorphic and igneous terranes in Chile, Bulgaria and other countries. He was also a friend of Bulgaria, which he visited in 1981.

The life story of Stephen Moorbath (born as Erwin Mosebach in the family of the Jewish medical doctor Heinz Mosebach and his wife Else in Magdeburg, Germany) resembles a tale: happy in the very early days, sad and grim in his childhood after 1933 in Nazi Germany, and rewarding and fulfilled in his new adoptive country, the United Kingdom. In 1938, his entire family was taken to a concentration camp, and he was saved by catholic nuns. After one year in Buchenwald, his father was released because he had fought for Germany in the First World War and had received the Iron Cross for his bravery; and he found a British sponsor thus enabling him and Erwin to leave Germany for the U.K. where they found their second Fatherland. Unfortunately, all other members of the family, including Else, the grandparents and other relatives, perished in the Holocaust.

In Oxford, Stephen left school in 1945, worked as laboratory technician at the University, and afterwards, as Assistant Experimental Officer at the UK Atomic Energy Authority in Harwell. After graduating Chemistry in 1954 from Oxford University again, he became interested in geology and combined his chemical and geological skills in founding, in 1956, the Geological Age and Isotope Research Group and laboratory (first in the U.K.). I am tempted to cite here Stephen's words about geology said during his interview with Vicky Leon in 2010: "The main reason I wanted to study it [geology]? The geological sciences provide such a wonderful and truthful picture of the origin, evolution, and structure of our planet throughout the whole of geological history - and of the evolution of all living creatures inhabiting the planet. All

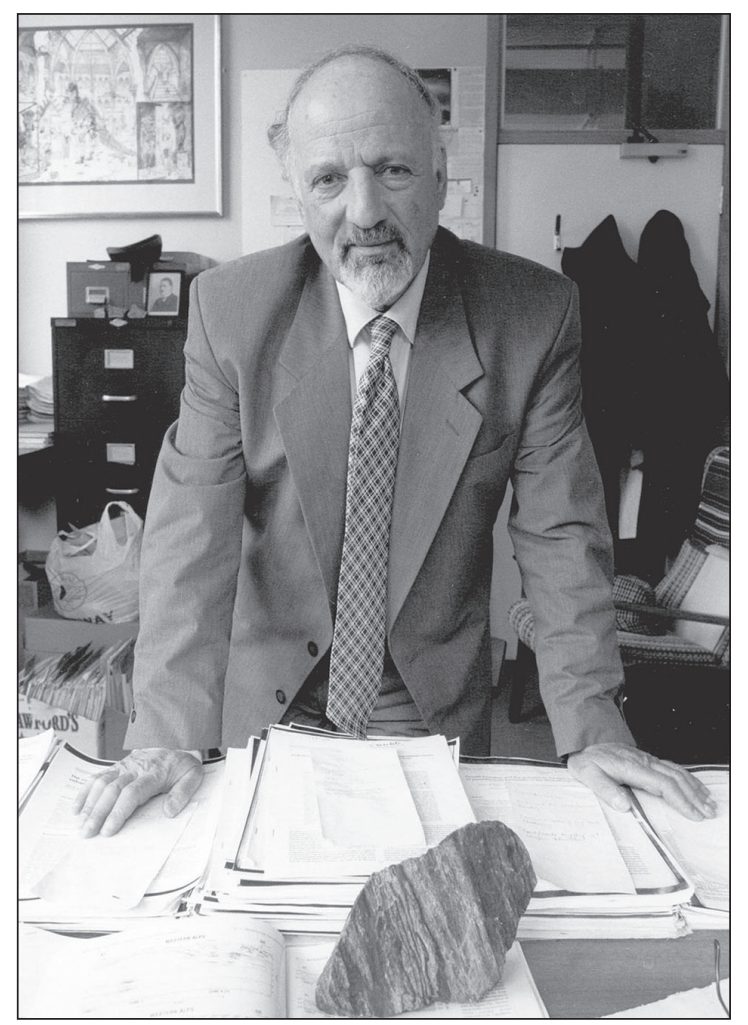

this is so much more realistic and intellectually satisfying than the picturesque but totally inaccurate creation myths of religious texts." And Stephen was always a real geologist, with 15 field trips in Greenland and many others all around the world: Scotland, Norway, Iceland, Zimbabwe, India, the Americas, Yemen, Spain, Italy, Switzerland, Bulgaria, and so on.

S. Moorbath obtained his Ph.D. degree in 1959 in Oxford and became Director of the Laboratory. Professor, elected in 1977 a Fellow of the Royal Society (FRS), Stephen Moorbath was awarded by the Geological Society of London the Wollaston Fund Award in 1970, and the Murchison Medal in 1978, in 1979 - the Steno Medal by the Danish Geological Society, the Rutherford Memorial Lecture in 1981 in Zimbabwe, and in 2004 - the International Ingerson Lecture 
award. Professor Emeritus since his retirement in 1998, Stephen continued his active scientific life. He was always deeply interested in the most ancient history of our planet and published important contributions on the geochemical features of the early Earth, the origin of life, and its early evolution, etc. The principal result of his studies during nearly 60 years is the modern vision on the Hadean and Archaean evolution of our planet: formation of a basaltic protocrust and the first felsic material supplying the first $\sim 4.4$ Ga detrital zircons; oldest ( $\sim 4.0-3.9 \mathrm{Ga}$ ) preserved continental crust, and the oldest mafic/ultramafic lavas, chemogenic and clastic sediments, and metagranites (at about $3.8 \mathrm{Ga}$ ); onset of tectonic subduction, and beginning of carbonate sedimentation (at $\sim 3.7 \mathrm{Ga}$ ).

The scientific legacy of Prof. Stephen Moorbath has impressive dimensions. The list of his publications at Scopus contains 120 documents, about 6,000 citations and $h_{\mathrm{i}}$ of 42 . Other publications outside this list include also eight papers published in the Bulgarian journals Geologica Balcanica and Review of the Bulgarian Geological Society. He made the Department of Geological Sciences at the University of Oxford one of the few leading world centers of isotopic geochemistry and geochronology. Something more - he built the bridges between fieldwork and the lab. As a result, the synthesis of regional geology, igneous and metamorphic petrology, geochemistry, isotopic geology, and geotectonics and structural geology has been achieved, and Stephen was one of the principal engineers of this development of modern geosciences. In his laboratory, he developed the rubidium-strontium method and, together with his collaborators, applied it together with the uranium-lead and samariumneodymium methods to some of the most important and most ancient metamorphic terranes in the world. Thus, he dated at more than $3.8 \mathrm{Ga}$ the oldest known rocks on the Earth from West Greenland. In Scotland, he dated the oldest Lewisian rocks at more than 2.9 $\mathrm{Ga}$ (by U-Pb studies), and by $\mathrm{Rb}-\mathrm{Sr}$ and $\mathrm{U}-\mathrm{Pb}$ studies, the Scourian $(2.6 \mathrm{Ga})$ and the Laxfordian $(1.6 \mathrm{Ga})$ gneisses, thus demonstrating the large time gap (previously supposed by J. Sutton and J. Watson) between the two cycles. He dated also the Torridonian com- plex, determined the mineral ages (Ordovician and Silurian, 450-420 Ma) of the Caledonides in the British Isles, and related these ages to the uplift and cooling. S. Moorbath dated also some of the oldest rocks in India and Zimbabwe.

The tectonothermal reworking of mantle and crust in plate tectonic settings was another favorite research subject for Stephen. Thus, he demonstrated the mantle origin of the Iceland volcanics and that the Tertiary acid magmas of the Isle of Skye are re-melted Lewisian gneisses. Igneous processes within the Andeantype orogen of the Andes attracted him to the high mountains of South America. The research on these processes resulted in a series of publications including the establishment of the more general MASH model for the origin and evolution of magmas.

I had the chance to meet Stephen in 1973, in Keele, during the International University Congress. He had been invited by the students to give a lecture on the then developing new methods of isotopic geochronology. After this first conversation, he invited me to visit his laboratory in Oxford, which was followed by an informal collaboration: visit to Bulgaria with extensive sampling and consecutive dating: of Hercynian granites in the Sredna gora Mts., with indicating their crustal origin (with some mantle supply for the first granitoid complex); of Alpine granites in Pirin; determination of rubidium and strontium geochemical features of the Bachkovo quartzo-feldspathic gneisses and indications for their behaviour during the Alpine tectonometamorphic events in the Rhodopes, and determination of a Rb-Sr age of the Vitosha pluton with isotopic evidence for a mantle origin of its magmas. During our field trip, Stephen was deeply interested in Bulgarian geology, history, and culture and impressed me with his wide knowledge and interests.

Stephen Moorbath will remain a key personality in the history of British science and of the world's modern isotopic geochemistry.

Bulgarian geologists extend their deepest sympathies to the family of Prof. Stephen Moorbath. He will also remain in the history of Bulgarian geology and in the hearts of everybody who has the privilege to have known him.

Ivan Zagorchev

\section{REFERENCES}

"A Fresh Eye" interview. 2010. Vicky Leon Interview with Stephen Moorbath (2010) http://vickileon.com/blog/

NATIONAL LIFE STORIES. AN ORAL HISTORY OF BRITISH SCIENCE. Professor Stephen Moorbath. 2011. Interviewed by Dr Paul Merchant. C1379/36. http://sounds. bl.uk

Nazi Germany escapee who became world leading geologist dies. The Oxford Times. 2016. http://www.oxfordtimes. co.uk/news/14925871.

\section{CONTRIBUTIONS OF PROF. S. MOORBATH TO THE GEOLOGY OF BULGARIA}

Moorbath, S., Zagorchev, I. 1983. Rubidium-strontium data on the age of the first granitoid complex (Smilovene and Hisar plutons) in Sashtinska Sredna gora. Geologica Balcanica 13 (3), 3-14 (in Russian, with English abstract).

Zagorchev, I., Moorbath, S. 1983. Rubidium-strontium data on the age of the Dautov pluton (granitoids of Pirin type), Southwest Bulgaria. Geologica Balcanica 13 (4), 31-37 (in Russian, with English abstract). 
Zagorchev, I., Moorbath, S. 1986. Problems of the metamorphism in the Central Rhodopes in the light of Rb-Sr isotopic data. Geologica Balcanica 16 (6), 61-78 (in Russian, with English abstract).

Zagorchev, I., Moorbath, S. 1986. Dating the granitoid magmatism in Sashtinska Sredna gora by the rubidium-strontium isochrones method. Review of the Bulgarian Geological Society 47 (3), 62-68 (in Bulgarian).

Zagorchev, I., Moorbath, S., Lilov, P. 1987. Radiogeochronological data on the Alpine magmatism in the western parts of the Rhodope massif. Geologica Balcanica 17 (2), 59-71 (in Russian, with English abstract).

Zagorchev, I., Moorbath, S. 1987. Rubidium-strontium isotopic data for Vitosha Pluton, Srednogorie Zone. Geologica Balcanica 17 (6), 43-48.

Zagorchev, I., Moorbath, S. 1988. Radiogeochronological data on the age of the granitoids South of the town of Tran, Southwest Bulgaria. Geologica Balcanica 18 (3), 43-46 (in Russian, with English abstract).

Zagorchev, I., Lilov, P., Moorbath, S. 1989. Results of the rubidium-strontium and potassium-argon radiogeochronological studies on the metamorphic and igneous rocks of South Bulgaria. Geologica Balcanica 19 (3), 41-54 (in Russian, with English abstract).

\section{SELECTED PUBLICATIONS OF PROF. STEPHEN MOORBATH}

André, L., Cardinal, D., Alleman, L. Y., Moorbath, S. 2006. Silicon isotopes in $\sim 3.8 \mathrm{Ga}$ West Greenland rocks as clues to the Eoarchean supracrustal Si cycle. Earth and Planetary Science Letters 245 (1-2), 162-173.

Appel, P. W. U., Fedo, C. M., Moorbath, S., Myers, J. S. 1998. Recognizable primary volcanic and sedimentary features in a low-strain domain of the highly deformed, oldest known ( 3.7-3.8 Gyr) greenstone belt, Isua, West Greenland. Terra Nova 10 (2), 57-62.

Appel, P. W. U., Moorbath, S., Myers, J. S. 2003. Isuasphaera isua (Pflug) revisited. Precambrian Research 126 (3-4), 309-312.

Appel, P. W. U., Moorbath, S., Touret, J. L. R. 2003. Early Archaean processes and the Isua greenstone belt, West Greenland. Precambrian Research 126 (3-4), 173-179.

Bolhar, R., Kamber, B. S., Moorbath, S., Fedo, C. M., Whitehouse, M. J. 2004. Characterisation of early Archaean chemical sediments by trace element signatures. Earth and Planetary Science Letters 222 (1), 43-60.

Bolhar, R., Kamber, B. S., Moorbath, S., Whitehouse, M. J., Collerson, K. D. 2005. Chemical characterization of Earth's most ancient clastic metasediments from the Isua Greenstone Belt, southern West Greenland. Geochimica et Cosmochimica Acta 69 (6), 1555-1573.

Caro, G., Bourdon, B., Birck, J., Moorbath, S. 2003. ${ }^{146} \mathrm{Sm}-$ ${ }^{142} \mathrm{Nd}$ evidence from Isua metamorphosed sediments for early differentiation of the Earth's mantle. Nature 423 (6938), 428-432.

Caro, G., Bourdon, B., Birck, J., Moorbath, S. 2006. High-precision ${ }^{142} \mathrm{Nd} /{ }^{144} \mathrm{Nd}$ measurements in terrestrial rocks: Constraints on the early differentiation of the Earth's mantle. Geochimica et Cosmochimica Acta 70, 1, 164-191.

Chapman, H. J., Moorbath, S. 1977. Lead isotope measurements from the oldest recognised Lewisian gneisses of north-west Scotland. Nature 268 (5615), 41-42.

Czaja, A. D., Johnson, C. M., Beard, B. L., Roden, E. E., Li, W., Moorbath, S. 2013. Biological Fe oxidation controlled deposition of banded iron formation in the ca. $3770 \mathrm{Ma}$ Isua supracrustal belt (West Greenland). Earth and Planetary Science Letters 363, 192-203.

Davidson, J. P., McMillan, N. J., Moorbath, S., Wörner, G., Harmon, R. S., Lopez-Escobar, L. 1990. The Nevados de Payachata volcanic region $\left(18^{\circ} \mathrm{S} / 69^{\circ} \mathrm{W}, \mathrm{N}\right.$. Chile) II. Evidence for widespread crustal involvement in Andean magmatism. Contributions to Mineralogy and Petrology 105 (4), 412-432.

Déruelle, B., Harmon, R. S., Moorbath, S. 1983. Combined $\mathrm{Sr}-\mathrm{O}$ isotope relationships and petrogenesis of Andean volcanics of South America. Nature 302 (5911), 814-816.

Dewey, J. F., McKerrow, W. S., Moorbath, S. 1970. The relationship between isotopic ages, uplift and sedimentation during Ordovician times in western Ireland. Scottish Journal of Geology 6 (2), 133-145.

Dickin, A. P., Moorbath, S., Welke, H. J. 1982. Isotope, trace element and major element geochemistry of Tertiary igneous rocks, Isle of Arran, Scotland. Transactions of the Royal Society of Edinburgh Earth Sciences 72 (3), 159-170.

Eglinton, G., Henderson-Sellers, A., Moorbath, S. 1981. Cosmochemistry and the origin of life. Nature, 292 (5825), 669.

Fairbairn, H. W., Moorbath, S., Ramo, A. O., Pinson Jr., W. H., Hurley, P. M. 1967. Rb-Sr age of granitic rocks of southeastern Massachusetts and the age of the Lower Cambrian at Hoppin Hill. Earth and Planetary Science Letters 2 (4), 321-328.

Francis, P. W., Moorbath, S., Thorpe, R. S. 1977. Strontium isotope data for recent andesites in Ecuador and north Chile. Earth and Planetary Science Letters 37 (2), 197-202.

Francis, P. W., Moorbath, S., Welke, H. J. 1971. Isotopic age data from Scourian intrusive rocks on the Isle of Barra, Outer Hebrides, north-west Scotland. Geological Magazine 108 (1), 13-21.

Francis, P. W., Thorpe, R. S., Moorbath, S., Kretzschmar, G. A., Hammill, M. 1980. Strontium isotope evidence for crustal contamination of calc-alkaline volcanic rocks from Cerro Galan, Northwest Argentina. Earth and Planetary Science Letters 48 (2), 257-267.

Gale, N. H., Moorbath, S., Simons, J., Walker, G. P. L. 1966. $\mathrm{K}-\mathrm{Ar}$ ages of acid intrusive rocks from Iceland. Earth and Planetary Science Letters 1 (5), 284-288.

Giletti, B. J., Lambert, R. S. J., Moorbath, S. 1961. The basement rocks of Scotland and Ireland. Annals of the New York Academy of Sciences 91 (2), 464-468. doi:10.1111/j.1749-6632.1961.tb35506.x

Giletti, B. J., Moorbath, S., Lambert, R. S. J. 1961. A geochronological study of the metamorphic complexes of the Scottish Highlands. Quarterly Journal of the Geological Society of London 117 (1-4), 233-264.

Hawkesworth, C. J., Moorbath, S., O’Nions, R. K., Wilson, J. F. 1975. Age relationships between greenstone belts and "granites" in the Rhodesian Archaean craton. Earth and Planetary Science Letters 25 (3), 251-262.

Hildreth, W., Moorbath, S. 1988. Crustal contributions to arc magmatism in the Andes of central Chile. Contributions to Mineralogy and Petrology 98 (4), 455-489.

Johnson, K. E., Harmon, R. S., Richardson, J. M., Moorbath, S., Strong, D. F. 1996. Isotope and trace element geochemistry of Augustine volcano, Alaska: Implications for magmatic evolution. Journal of Petrology 37 (1), 95-115.

Kamber, B. S., Collerson, K. D., Moorbath, S., Whitehouse, M. J. 2003. Inheritance of early Archaean Pb-isotope variability from long-lived Hadean protocrust. Contributions to Mineralogy and Petrology 145 (1), 25-46.

Kamber, B. S., Moorbath, S. 1998. Initial Pb of the Amitsoq gneiss revisited: Implication for the timing of early Archaean crustal evolution in West Greenland. Chemical Geology 150 (1-2), 19-41. 
Kamber, B. S., Whitehouse, M. J., Bolhar, R., Moorbath, S. 2005. Volcanic resurfacing and the early terrestrial crust: Zircon U-Pb and REE constraints from the Isua Greenstone Belt, southern West Greenland. Earth and Planetary Science Letters 240 (2), 276-290.

Kempton, P. D., Harmon, R. S., Hawkesworth, C. J., Moorbath, S. 1990. Petrology and geochemistry of lower crustal granulites from the Geronimo volcanic field, southeastern Arizona. Geochimica et Cosmochimica Acta 54 (12), 3401-3426.

McMillan, N. J., Davidson, J. P., Worner, G., Harmon, R. S., Moorbath, S., Lopez-Escobar, L. 1993. Influence of crustal thickening on arc magmatism: Nevados de Payachata volcanic region, northern Chile. Geology 21 (5), 467-470.

McMillan, N. J., Harmon, R. S., Moorbath, S., Lopez-Escobar, L., Strong, D. F. 1989. Crustal sources involved in continental arc magmatism: A case study of volcano MochoChoshuenco, southern Chile. Geology 17 (12), 1152-1156.

Michard-Vitrac, A., Lancelot, J., Allègre, C. J., Moorbath, S. 1977. U-Pb ages on single zircons from the Early Precambrian rocks of West Greenland and the Minnesota River Valley. Earth and Planetary Science Letters 35 (3), 449453.

Moorbath, S. 1959. Isotopic composition of lead from British mineral deposits. Nature 183 (4661), 595-596.

Moorbath, S. 1967. Recent advances in the application and interpretation of radiometric age data. Earth-Science Reviews $3,111-133$.

Moorbath, S. 1969. Evidence for the age of deposition of the Torridonian sediments of north-west Scotland. Scottish Journal of Geology 5 (2), 154-170.

Moorbath, S. 1975. Evolution of Precambrian crust from strontium isotopic evidence. Nature 254 (5499), 395-398.

Moorbath, S. 1975. Geological interpretation of whole-rock isochron dates from high grade gneiss terrains. Nature 255 (5507), 391.

Moorbath, S. 1977. Ages, isotopes and evolution of Precambrian continental crust. Chemical Geology 20, 151-187.

Moorbath, S. 1978. Timing of continental growth and emergence. Nature 273 (5657), 75-76.

Moorbath, S. 1983. Origin of granitoid rocks. Nature 305 (5929), 73.

Moorbath, S. 1984. Origin of granulites. Nature 312 (5991), 290.

Moorbath, S. 1985. Crustal evolution in the early Precambrian. Origins of Life and Evolution of the Biosphere 15 (4), 251-261.

Moorbath, S. 1986. Precambrian geology: The most ancient rocks revisited. Nature 321 (6072), 725.

Moorbath, S. 1991. Problems of British science. Nature 353 (6343), 378.

Moorbath, S. 1995. Age of the oldest rocks with biogenic components. An estimate for the age of the origin of life. Journal of Biological Physics 20 (1-4), 85-94.

Moorbath, S. 2005. Dating earliest life. Nature 434 (7030), 155.

Moorbath, S. 2005. Oldest rocks, earliest life, heaviest impacts, and the Hadean-Archaean transition. Applied Geochemistry 20 (5), 819-824.

Moorbath, S. 2005. Palaeobiology: Dating earliest life. Nature 434 (7030), 155.

Moorbath, S. 2009. The discovery of the Earth's oldest rocks. Notes and Records of the Royal Society 63 (4), 381-392.

Moorbath, S., Allaart, J. H., Bridgwater, D., McGregor, V. R. 1977. Rb-Sr ages of early Archaean supracrustal rocks and Amîtsoq gneisses at Isua. Nature 270 (5632), 43-45.

Moorbath, S., Bell, J. D. 1965. Strontium isotope abundance studies and rubidium-strontium age determinations on Tertiary igneous rocks from the Isle of Skye, north-west Scotland. Journal of Petrology 6 (1), 37-66.
Moorbath, S., Hurley, P. M., Fairbairn, H. W. 1967. Evidence for the origin and age of some mineralized Laramide intrusives in the southwestern United States from strontium isotope and rubidium-strontium measurements. Economic Geology 62 (2), 228-236.

Moorbath, S., O’Nions, R. K., Pankhurst, R. J. 1973. Early Archaean age for the Isua Iron Formation, West Greenland. Nature 245 (5421), 138-139.

Moorbath, S., O’Nions, R. K., Pankhurst, R. J. 1975. The evolution of early Precambrian crustal rocks at Isua, West Greenland - geochemical and isotopic evidence. Earth and Planetary Science Letters 27 (2), 229-239.

Moorbath, S., Shackleton, R. M. 1966. Isotopic ages from the Precambrian Mona Complex of Anglesey, North Wales (Great Britain). Earth and Planetary Science Letters 1 (3), 113-117.

Moorbath, S., Sigurdsson, H., Goodwin, R. 1968. K/Ar ages of the oldest exposed rocks in Iceland. Earth and Planetary Science Letters 4 (3), 197-205.

Moorbath, S., Stewart, A. D., Lawson, D. E., Williams, G. E. 1967. Geochronological studies on the Torridonian sediments of north-west Scotland. Scottish Journal of Geology 3 (3), 389-412.

Moorbath, S., Taylor, P. N. 1986. Geochronology and related isotope geochemistry of high-grade metamorphic rocks from the lower continental crust. In: Dawson, J.B., Carswell, D.A., Hall, J., Wederpohl, K.H. (Eds). The Nature of the Lower Continental Crust, Geological Society, London, Special Publications No. 24, 211-220.

Moorbath, S., Taylor, P. N., Goodwin, R. 1981. Origin of granitic magma by crustal remobilisation: $\mathrm{Rb}-\mathrm{Sr}$ and $\mathrm{Pb} / \mathrm{Pb}$ geochronology and isotope geochemistry of the late Archaean Qôrqut Granite Complex of southern West Greenland. Geochimica et Cosmochimica Acta 45 (7), 1051-1060.

Moorbath, S., Taylor, P. N., Jones, N. W. 1986. Dating the oldest terrestrial rocks - fact and fiction. Chemical Geology 57 (1-2), 63-86.

Moorbath, S., Taylor, P. N., Orpen, J. L., Treloar, P., Wilson, J. F. 1987. First direct radiometric dating of Archaean stromatolitic limestone. Nature 326 (6116), 865-867.

Moorbath, S., Thompson, R. N. 1980. Strontium isotope geochemistry and petrogenesis of the early Tertiary lava pile of the Isle of Skye, Scotland, and other basic rocks of the British Tertiary Province: An example of magma-crust interaction. Journal of Petrology 21 (2), 295-321.

Moorbath, S., Thorpe, R. S., Gibson, I. L. 1978. Strontium isotope evidence for petrogenesis of Mexican andesites. $\mathrm{Na}$ ture 271 (5644), 437-439.

Moorbath, S., Welke, H. 1968. Lead isotope studies on igneous rocks from the Isle of Skye, Northwest Scotland. Earth and Planetary Science Letters 5, 217-230.

Moorbath, S., Welke, H., Gale, N. H. 1969. The significance of lead isotope studies in ancient, high-grade metamorphic basement complexes, as exemplified by the Lewisian rocks of Northwest Scotland. Earth and Planetary Science Letters 6 (4), 245-256.

Moorbath, S., Whitehouse, M. J., Bowring, S. A., Housh, T. 1996. Sm-Nd isotopic data and Earth's evolution. Science 273 (5283), 1878-1879.

Moorbath, S., Whitehouse, M. J., Kamber, B. S. 1997. Extreme Nd-isotope heterogeneity in the early Archaean - fact or fiction? Case histories from northern Canada and West Greenland. Chemical Geology 135 (3-4), 213-231.

Moorbath, S., Wilson, J. F., Cotterill, P. 1976. Early Archaean age for the Sebakwian Group at Selukwe, Rhodesia. Nature 264 (5586), 536-538.

Moorbath, S., Wilson, J. F., Goodwin, R., Humm, M. 1977. Further Rb-Sr age and isotope data on Early and Late Ar- 
chaean rocks from the Rhodesian craton. Precambrian Research 5 (3), 229-239.

Pankhurst, R. J., Moorbath, S., Rex, D. C., Turner, G. 1973. Mineral age patterns in ca. 3700 my old rocks from West Greenland. Earth and Planetary Science Letters 20 (2), $157-170$

Pearce, J. A., Bender, J. F., De Long, S. E., Kidd, W. S. F., Low, P. J., Güner, Y., Mitchell, J. G. 1990. Genesis of collision volcanism in eastern Anatolia, Turkey. Journal of Volcanology and Geothermal Research 44 (1-2), 189-229.

Ramakrishnan, M., Moorbath, S., Taylor, P. N., Anantha Iyer, G. V., Viswanatha, M. N. 1984. Rb-Sr and Pb-Pb wholerock isochron ages of basement gneisses in Karnataka craton. Journal of Geological Society of India 25 (1), 20-34.

Schoenberg, R., Kamber, B. S., Collerson, K. D., Moorbath, S. 2002. Tungsten isotope evidence from $\sim 3.8-\mathrm{Gyr}$ metamorphosed sediments for early meteorite bombardment of the Earth. Nature 418 (6896), 403-405.

Smith, P. E., Evensen, N. M., York, D., Moorbath, S. 2005. Oldest reliable terrestrial ${ }^{40} \mathrm{Ar}-{ }^{39} \mathrm{Ar}$ age from pyrite crystals at Isua, west Greenland. Geophysical Research Letters 32 (21), 1-4.

Taylor, P. N., Chadwick, B., Moorbath, S., Ramakrishnan, M., Viswanatha, M. N. 1984. Petrography, chemistry and isotopic ages of peninsular gneiss, Dharwar acid volcanic rocks and the Chitradurga granite with special reference to the late Archaean evolution of the Karnataka craton, southern India. Precambrian Research 23 (3-4), 349-375.

Taylor, P. N., Jones, N. W., Moorbath, S. 1984. Isotopic assessment of relative contributions from crust and mantle sources to the magma genesis of Precambrian granitoid rocks. Philosophical Transactions of the Royal Society of London (A310), 1514.

Taylor, P. N., Moorbath, S., Leube, A., Hirdes, W. 1992. Early Proterozoic crustal evolution in the Birimian of Ghana: Constraints from geochronology and isotope geochemistry. Precambrian Research 56 (1-2), 97-111.

Thorpe, R. S., Francis, P. W., Moorbath, S. 1979. Strontium isotope evidence for petrogenesis of central American andesites [4]. Nature 277 (5691), 44-45.

Turnbull, M. J. M., Whitehouse, M. J., Moorbath, S. 1996. New isotopic age determinations for the Torridonian, NW Scotland. Journal of the Geological Society 153 (6), 955-964.

Welke, H., Moorbath, S., Cumming, G. L., Sigurdsson, H. 1968. Lead isotope studies on igneous rocks from Iceland. Earth and Planetary Science Letters 4 (3), 221-231.

Whitehouse, M. J., Kamber, B. S., Moorbath, S. 1999. Age significance of $\mathrm{U}-\mathrm{Th}-\mathrm{Pb}$ zircon data from early Archean rocks of West Greenland - a reassessment based on combined ion-microprobe and imaging studies. Chemical Geology 160 (3), 201-224.

Whitehouse, M. J., Moorbath, S. 1986. Pb-Pb systematics of Lewisian gneisses - implications for crustal differentiation. Nature 319 (6053), 488-489.

Willbold, M., Elliott, T., Moorbath, S. 2011. The tungsten isotopic composition of the Earth's mantle before the terminal bombardment. Nature 477 (7363), 195-198.

Worner, G., Moorbath, S., Harmon, R. S. 1992. Andean Cenozoic volcanic centres reflect basement isotopic domains. Geology 20 (12), 1103-1106. 